Research Article

\title{
Effect of Dietary Selenium on Protein and Lipid Oxidation and the Antioxidative Potential of Selected Chicken Culinary Parts during Frozen Storage
}

\author{
Małgorzata Korzeniowska (D), ${ }^{1}$ Bożena Króliczewska, ${ }^{2}$ and Wiesław Kopeć ${ }^{1}$ \\ ${ }^{1}$ Department of Animal Products Technology and Quality Management, Wrocław University of Environmental and Life Sciences, \\ 37 Chełmońskiego Str., 51-630 Wrocław, Poland \\ ${ }^{2}$ Department of Animal Physiology and Biostructure, Faculty of Veterinary Medicine, \\ Wroclaw University of Environmental and Life Sciences, Norwida Str. 31, 50-375 Wroclaw, Poland
}

Correspondence should be addressed to Małgorzata Korzeniowska; malgorzata.korzeniowska@upwr.edu.pl

Received 8 June 2018; Revised 24 August 2018; Accepted 2 September 2018; Published 27 September 2018

Guest Editor: Agnieszka Saeid

Copyright ( 2018 Małgorzata Korzeniowska et al. This is an open access article distributed under the Creative Commons Attribution License, which permits unrestricted use, distribution, and reproduction in any medium, provided the original work is properly cited.

\begin{abstract}
The objective of the study was to evaluate the effects of inorganic and organic selenium in the diet of broiler chickens on the oxidative changes in the functional groups of proteins and total lipids, as well as the antioxidative potential of typical culinary parts fresh and frozen. Materials used in the nutrition study comprises one-day-old Flex broiler chickens randomly allocated to three dietary treatments: Control and SeN-fed diet enriched with $0.50 \mathrm{mg} / \mathrm{kg}$ of inorganic selenium (sodium selenite), and SeO-fed with diet containing $0.50 \mathrm{mg} / \mathrm{kg}$ of selenized yeast Yarrowia lipolytica. After slaughter, chicken carcasses were divided into the most typical culinary parts i.e., wings, outer and deep breasts, drumstick, thigh and back and analyzed in the fresh state and during frozen storage at $-18^{\circ} \mathrm{C}$ until 90 days. The analyses undertaken during the study measured selenium concentration, $\mathrm{CO}, \mathrm{SH}$, and $\mathrm{NH}_{2}$ groups in the proteins, TBARS-expressing changes in the lipids, and antioxidative potential by ABTS, DPPH, and FRAP methods. The results of the study showed that the dietary selenium supplementation effectively increased the selenium concentration in all analyzed culinary parts of the chicken carcass, especially high in leg muscles. Selenium supplementation of the chicken diet significantly reduced the oxidative changes in the most important chemical reactive groups of the muscle myofibrillar proteins in all analyzed culinary parts. Both forms of selenium, organic and inorganic, were able to slow down the oxidation processes during first 30 days of the frozen storage of the meat. Longer storage could be only recommended for breast fillets, definitely not for the back part. The effect was much stronger in case of an organic selenium supplementation comparing to inorganic form of diet enrichment.
\end{abstract}

\section{Introduction}

In recent years, the interest in free-radical chemistry has been increased. The highly reactive molecules called free radicals are generated by various endogenous systems in the body, due to exposure to different physiochemical conditions or pathological states $[1,2]$. Oxidative processes are complex reactions initiated in meat pigments, different classes of lipids, and proteins forming a variety of oxidation products [3]. Free radicals as an effect of oxidative metabolism can cause tissue damage by reacting with polyunsaturated fatty acids in cellular membranes, nucleotides in DNA, and critical sulfhydryl bonds in proteins $[4,5]$.
Nowadays, there is interest in the food that characterizes beneficial effects on human health. Chicken meat is important in human nutrition due to a low amount of total fat and cholesterol content [6]. Moreover, chicken fat contains relatively high amount (25-30\%) of polyunsaturated fatty acids (PUFA), as well as approximately $40 \%$ of monounsaturated fatty acids (MUFA) [7]. However, chicken meat enriched with PUFA contains longer fatty acids with a high number of double bonds, which increases the susceptibility of meat to oxidation processes $[3,8,9]$. Lipid oxidation causes loss of nutritional and sensory values, as well as the formation of potentially toxic compounds that compromise meat quality and reduce its shelf life [3]. The high levels of 
oxidation of lipids produce free radicals, which are associated with mutagenesis, carcinogenesis, and aging [2]. Notably, lipid oxidation is the limiting factor for PUFAs to serve as nutritionally beneficial lipids in functional foods [10].

Furthermore, chicken meat contains high biological value proteins $(20-22 \%)$, which can also be affected by the oxidative reactions $[6,11]$. The impact of protein oxidation on meat quality is still the subject of multiple studies, but it is generally accepted that this reaction is commonly linked to a loss of nutritional value and a decrease in muscle protein functionality, leading to increasing water losses, weaker protein gel formation, and less stable emulsions [12]. Generally, it was concluded that the presence of Se in animal diets is essential for water retention properties of meat, but it is inconclusive whether the form of Se is always important in controlling meat drip loss [13]. Moreover, the texture and color deterioration of meat has been related to the protein oxidation phenomenon [14]. Muscle proteins are a major target of ROS; the accumulation of oxidized products in the muscle tissue leads to meat quality deterioration. Oxidative modification of proteins and formation of carbonyl derivatives have a harmful effect on meat quality, and protein carbonyl content increased during storage. However, muscle samples from antioxidant-supplemented diets had lower carbonyl content $[15,16]$.

As mentioned earlier, free radicals are generated not only by various endogenous systems. Furthermore, exposure to different physiochemical conditions can lead to oxidation processes [1]. Freezing and frozen storage is an essential step to achieving a safe product, but it depends on the conditions applied. They can accelerate the oxidation processes that damage the meat quality and nutritional value [4]. Freezing is a widely accepted preservation method used to store meat for relatively long periods of time. In this process, intracellular juice is expelled by osmosis to the extracellular space, forming ice crystals that later cause juice loss from meat during thawing [17]. The freezing rate, frozen storage temperature, and duration may affect the amount of intracellular ice formation and physical destruction of muscle and strongly influence the quality attributes of meat and meat products $[18,19]$. Freezing probably affects meat oxidation by causing damage to certain cellular structures, especially membrane lipids [20]. On summarizing, freezing can extend storage from a food-safety standpoint but does not completely prevent oxidations of lipids and proteins [21].

The negative consequences of oxidation processes can be overcome by the use of antioxidants in the diet, such as selenium (Se).

Selenium is an essential trace element which plays an important role in antioxidant protection against oxidative stress initiated by excess reactive oxygen species (ROS) and reactive nitrogen species (NOS) [22, 23]. Se was identified as a component (cofactor) in various selenoproteins and selenoenzymes as the antioxidant enzyme glutathione peroxidase (GSH-Px), which participates in redox regulation by removing and decomposing hydrogen peroxide and lipid hydroperoxides using glutathione as the electron donor [24]. The greater amount of Se present in the tissue of broilers fed an antioxidant-supplemented diet would conceivably promote glutathione peroxidase activity. Moreover, antioxidant functions of Se have also been shown to persist in postmortem muscle tissue, and these effects of selenium are manifested in meat quality by reduced oxidization of lipids $[15,25,26]$. It was observed that lipid peroxidation in plasma decreased, while activities of GPx and glutathione reductase in plasma increased linearly with various Se concentrations $(0,0.1,0.2,0.3$, or $0.4 \mathrm{mg} / \mathrm{kg}$ diet $)$ [27].

For this reason, various dietary strategies in animal feeding have been developed for providing Se-enriched meat in order to protect the quality of meat [28]. Pappas et al. [29] showed that addition of Se to chicken diets leads to production of Se-enriched meat, protection of healthpromoting fatty acids like C20:5n-3 and C22:6n-3, and protection of meat quality from oxidation after slaughter.

Therefore, the aim of this study was to evaluate the effects of inorganic and organic selenium in the diet of chickens on the changes in lipids and proteins functional groups as well as antioxidative potential of typical culinary parts of meat: wings, outer and deep breasts, drumstick, and thigh in the fresh meat and during frozen storage until 90 days. Furthermore, in accordance with EU regulations in the present study, we used the maximum permitted level of Se in the complete feed $(0.5 \mathrm{mg} \mathrm{Se} / \mathrm{kg})$ [30].

\section{Materials and Methods}

2.1. Experimental Design and Sample Preparation. One-day-old Flex broiler chickens (45 birds in total) (Hubbard, Poland) were randomly allocated to three dietary treatments: group I (Control) with no supplementation, group II (SeN) diet enriched with $0.50 \mathrm{mg} / \mathrm{kg}$ of inorganic selenium (sodium selenite, Sigma-Aldrich), and group III ( $\mathrm{SeO}$ ) fed with diet containing $0.50 \mathrm{mg} / \mathrm{kg}$ of organic selenium (selenized yeast rich mainly in selenomethionine). Importantly, it should be noted that the final analysis of Se concentration showed that in both diets Se concentration did not significantly exceed $0.5 \mathrm{mg} / \mathrm{kg}$ (Table 1 ).

Selenized yeasts Yarrowia lipolytica were prepared at the Department of Biotechnology and Food Microbiology, Wroclaw University of Environmental and Life Sciences. All diets were based on the standard commercially available feed mixture with added vitamin premix (Table 1). Chickens were treated equally in case of provided food and water, as well as living space, light, and veterinary treatment. For the initial 14-day period, the chicks were supplied with starter diet, followed by grower feed mixtures between 22 and 42 days. The feed provided about $220-200 \mathrm{~g}$ crude protein and 12.2-12.7 MJ energy in one kilogram of starter and grower mixtures, respectively. After 42 days of the nutrition study, all birds were slaughtered manually and were skinned and eviscerated. This study was carried out in accordance with the animal welfare recommendations of the European Union Directive $12586 / 609 /$ EEC. The protocol was approved by the Local Ethical Committee for Animal Experiments of Wroclaw University of Environmental and Life Sciences, Poland.

Collected carcasses were immediately chilled on ice to $2^{\circ} \mathrm{C}$. Prior to analyses, the carcasses were cut up to get typical 
TABle 1: Composition of experimental diets.

\begin{tabular}{lcccc}
\hline & & \multicolumn{3}{c}{ Grower } \\
& Starter & Control & $\begin{array}{c}\text { Organic Se } \\
0.50 \mathrm{mg}\end{array}$ & $\begin{array}{c}\text { Inorganic Se } \\
0.50 \mathrm{mg}\end{array}$ \\
\hline Mashed maize & 20.0 & 20.0 & 20.0 & 20.0 \\
Mashed wheat & 39.7 & 43.4 & 43.1 & 43.3 \\
Soy oil & 3.30 & 4.70 & 4.80 & 4.80 \\
Soya bean meal & 32.4 & 27.3 & 27.3 & 27.3 \\
Selenium yeast & & & 0.113 & \\
Sodium selenite & & & & 0.003 \\
Chalk & 0.37 & 0.36 & 0.36 & 0.36 \\
Premix dka-s/g & 4.00 & 4.00 & 4.00 & 4.00 \\
DL-methionine 98\% & 0.232 & 0.228 & 0.228 & 0.228 \\
EM (MJ) & 12.5 & 13.0 & 13.0 & 13.0 \\
Crude protein (g) & 227 & 205 & 200 & 197 \\
Crude fibre (g) & 28.7 & 27.8 & 27.8 & 27.8 \\
Crude fat (g) & 52.1 & 66.7 & 68.7 & 68.8 \\
Lysine (g) & 12.6 & 11.4 & 11.8 & 11.4 \\
Methionine (g) & 5.42 & 5.17 & 5.26 & 5.14 \\
Ca (g) & 9.30 & 9.19 & 9.33 & 9.28 \\
P (g) & 4.80 & 4.64 & 4.63 & 4.64 \\
Na (g) & 1.72 & 1.68 & 1.69 & 1.70 \\
Se (mg) & 0.154 & 0.143 & 0.503 & 0.497 \\
\hline 1kgefpremix proving
\end{tabular}

* $1 \mathrm{~kg}$ of premix provided: vitamin A (retinyl acetate) 10,000 IU; vitamin $\mathrm{D}_{3}$ (cholecalciferol) 2,000 IU; vitamin E (DL-a-tocopheryl acetate) $20 \mathrm{mg}$; vitamin $\mathrm{K}$ (hetrazeen vit. $\mathrm{K}_{3}$ free from menadione) $3 \mathrm{mg}$; vitamin $B_{1}$ (thiamine mononitrate) $2.5 \mathrm{mg}$; vitamin $\mathrm{B}_{6}$ (pyridoxine $\mathrm{HCl}$ ) $0.4 \mathrm{mg}$; vitamin $B_{12}$ (cyanocobalamin) $0.015 \mathrm{mg}$; choline (choline chloride) $450 \mathrm{mg}$; folic acid $1.2 \mathrm{mg}$; nicotic acid $25 \mathrm{mg}$; panthothenic acid $8 \mathrm{mg}$; DL-methionine $1.0 \mathrm{mg}, \mathrm{Fe}\left(\right.$ as $\left.\mathrm{FeSO}_{4} \cdot \mathrm{H}_{2} \mathrm{O}\right) 30 \mathrm{mg} ; \mathrm{Mn}\left(\right.$ as $\left.\mathrm{MnO}_{2}\right) 74 \mathrm{mg}$; $\mathrm{Cu}$ (as $\left.\mathrm{CuSO}_{4} \cdot 5 \mathrm{H}_{2} \mathrm{O}\right) 4 \mathrm{mg}$; $\mathrm{Zn}$ (as $\left.\mathrm{ZnO}\right) 45 \mathrm{mg}$; I (as $\left.\mathrm{Ca}\left(\mathrm{IO}_{3}\right)_{2}\right) 0.3 \mathrm{mg}$; Co (as $\left.\mathrm{CoCO}_{3}\right) 0.4 \mathrm{mg}$.

culinary parts (PN-92A-86521): chicken wing (foreleg removed from the carcass in the shoulder joint), outer (pectoralis major $\mathrm{m}$.) and deep (pectoralis minor $\mathrm{m}$.) breasts, drumstick (tibia and fibula bones with attached muscles), and thigh (femur bone with respective muscles); the remaining part was called back. All samples were all the time chilled on ice, then stored for seven days at $4^{\circ} \mathrm{C}$ (chilled samples). Frozen samples were obtained by freezing the meat directly after slaughter to internal $-18^{\circ} \mathrm{C}$ and storing at $-20^{\circ} \mathrm{C}$ up to 90 days. The analyses were done in the fresh meat and after 30,60, and 90 days of freezing. Directly before analyses, frozen muscles were defrosted on ice to an internal temperature of $-2^{\circ} \mathrm{C}$. The preparation of muscle samples began with the removal of any epimysial, connective tissue, visible fatty tissue, and covering muscle from frozen meat and cut into small pieces. 50 grams of the collected muscles from all respective culinary parts were homogenized with distilled water $(1: 3)$ for three minutes. Next, the homogenates were centrifugated for 15 minutes at $4^{\circ} \mathrm{C}$ at $15,000 \times \mathrm{g}$. The collected supernatant was then used for further analyses.

\subsection{Proximate, Basic Physicochemical Properties and Selenium} Analyses. Protein concentration was analyzed as overall nitrogen content based on the Kjeldahl method, and the protein content was calculated with the correlation ratio of 6.5. $\mathrm{pH}$ was analyzed by placing the blade electrode (SaqP 201) of the MAT-1202 pH-meter directly to the homogenized muscles (calibration on the standard pH solution of $\mathrm{pH} 4.0$ and 7.0. Dry matter content was analyzed by the drying method $\left(105^{\circ} \mathrm{C}\right)$. Chemical analysis of Se content in the meat and feed samples was carried out according to PN-EN 13805:2003 and PN-EN 14084:2004 with hydride generation atomic spectroscopy (Spectra AA240FS, Varian Analytical Instrument) after the acidic digestion. The technical parameters used for the analysis were $280 \mathrm{~V}$ of negative high voltage, $80 \mathrm{~mA}$ of the current of hollow cathode lamp, $7 \mathrm{~mm}$ of electrothermal atomizer height, pure argon as a carrier gas, $800 \mathrm{~mL} \cdot \mathrm{min}^{-1}$ of carrier flow, and $1.0 \mathrm{~mL}$ of the injecting sample. Protein content in the homogenates and supernatants was analyzed as previously described [31].

2.3. Reactive Chemical Groups. Reactive group content (carbonyl, sulfhydryl, and amine) in the chicken muscles was analyzed after myofibrillar proteins were extracted at $2^{\circ} \mathrm{C}$ by the procedure of Srinivasan et al. [32]. Briefly, the muscles were homogenized with $25 \mathrm{mM}$ phosphate buffer ( $\mathrm{pH} 7.0$ ) containing $100 \mathrm{mM} \mathrm{KCl}, 1 \mathrm{mM}$ EDTA, and $1 \mathrm{mM} \mathrm{NaN}_{3}(1$ : $4 \mathrm{v} / \mathrm{w})$. Homogenates were then centrifugated at $2,000 \times \mathrm{g}$, and the pellet was suspended, washed with fresh cold phosphate buffer, and then centrifugated at $12,000 \mathrm{x} \mathrm{g}$. Protein content was analyzed as described above.

2.3.1. Determination of Protein Carbonyl Groups Using Dinitrophenylhydrazine (DNPH). The content of carbonyl groups (CO) in chicken proteins was carried out by the derivatization with DNPH [33]. Myofibrillar proteins were homogenized 1:10 (w/v) with pyrophosphate buffer $(\mathrm{pH}$ 7.4) (PB) made out of $2.0 \mathrm{mM} \mathrm{Na}_{4} \mathrm{P}_{2} \mathrm{O}_{7}, 10 \mathrm{mM}$ tris-maleate, $100 \mathrm{mM} \mathrm{KCl}, 2.0 \mathrm{mM} \mathrm{MgCl}_{2}$, and $2.0 \mathrm{mM}$ EGTA using an ultraturrax homogenizer for $30 \mathrm{~s}$. The homogenates were equally divided into two aliquots of $0.1 \mathrm{~mL}$ and precipitated by adding $1 \mathrm{~mL}$ of $10 \% \mathrm{TCA}$, followed by centrifugation for $5 \mathrm{~min}$ at 5,000 $\mathrm{xg}$. The obtained pellet was treated with $1 \mathrm{~mL}$ $2 \mathrm{~N} \mathrm{HCl}$ (for quantifying protein concentration), and the

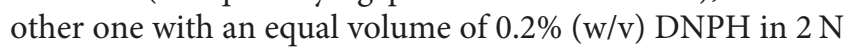
$\mathrm{HCl}$ (for carbonyl concentration measurement). Both samples were incubated for $60 \mathrm{~min}$ at room temperature without light exposure. Then, samples were precipitated with $1 \mathrm{~mL}$ of $10 \%$ TCA and washed twice with $1 \mathrm{~mL}$ of $1: 1$ ethanol/ethyl acetate (v/v), mixed, and centrifuged for $5 \mathrm{~min}$ at $10,000 \mathrm{x} \mathrm{g}$. The pellets were then dissolved in $1.5 \mathrm{~mL}$ of $20 \mathrm{mM}$ sodium phosphate buffer ( $\mathrm{pH} 6.5$ ) containing $6 \mathrm{M}$ guanidine hydrochloride, stirred, and centrifuged for $2 \mathrm{~min}$ at $5,000 \mathrm{rpm}$ to remove insoluble fragments. Protein concentration was calculated from absorption at $280 \mathrm{~nm}$ using bovine serum albumin (BSA) as a standard. The amount of carbonyls was measured at $370 \mathrm{~nm}$ and expressed as nmol of carbonyl per mg of protein using the adsorption coefficient for the protein hydrazones $\left(22.0 \mathrm{mM}^{-1} \cdot \mathrm{cm}^{-1}\right)$ [34].

2.3.2. Determination of Sulfhydryl Groups Using 5,5'Dithiobis(2-nitrobenzoic Acid) (DTNB). Total free sulfhydryl groups $(\mathrm{SH})$ concentration was measured in the 
reaction with DTNB [35]. Briefly, myofibrillar proteins were dissolved in $20.0 \mathrm{~mL}$ urea-SDS buffer $(8.0 \mathrm{M}$ urea, $3 \%$ SDS and $0.1 \mathrm{M}$ phosphate; $\mathrm{pH}$ 7.4) and left on the shaking bath at room temperature for $8 \mathrm{~h}$. After that, $1 \mathrm{~mL}$ of the protein solution was incubated with $0.3 \mathrm{~mL}$ DTNB reagent $(10 \mathrm{mM}$ DTNB in $0.1 \mathrm{M}$ phosphate buffer; $\mathrm{pH}$ 7.4) at room temperature for $15 \mathrm{~min}$. Finally, the absorbance of the samples was read at $412 \mathrm{~nm}$. Sample blank was run with $1.0 \mathrm{~mL}$ phosphate buffer without DTNB; reagent blank was run with water only. Sulfhydryl content was calculated using a molar absorptivity of $13,600 \mathrm{M}^{-1} \cdot \mathrm{cm}^{-1}$.

2.3.3. Free Amine Groups Determination in Proteins by Trinitrobenzenesulfonic Acid TNBS. Free amine group $\left(\mathrm{NH}_{2}\right)$ content was analyzed in the extracted myofibrillar proteins after precipitation with $20 \%$ TCA, followed by the reaction with picrylsulfonic acid (TNBS) [36]. The incubation time at $37^{\circ} \mathrm{C}$ was set for $5 \mathrm{~h}$. The absorbance of the solutions was evaluated at $340 \mathrm{~nm}$, and the results were calculated according to the standard curve.

2.4. Total Antioxidative Capacity (TAC). Briefly, the hydrophilic fraction of the samples was prepared by homogenization of muscles with distilled water (Mixer B-400 Buchi, Switzerland) followed by centrifugation and then used for the total antioxidative capacity assays such as radical scavenging assays using 2,2' -azino-bis-3-ethylbenzthiazoline-6-sulphonic acid (ABTS) and 2,2-diphenyl-1-picrylhydrazyl (DPPH) assay, ferric reducing antioxidant potential (FRAP) assay, and thiobarbituric acid reactive substances (TBARS) assay as previously described by Korzeniowska et al. [37].

2.5. The Extent of the Oxidation Processes by 2-Thiobarbituric Acid Reactive Substances Content. The extent of the oxidation processes was determined by the method described by Mei et al. [38]. Briefly, the muscle homogenates of $5 \mathrm{ml}$ were precipitated by the reaction with $10 \%$ TCA, followed by the centrifugation at $10,000 \mathrm{x}$ g. Collected supernatants were then equally treated with $2 \mathrm{ml}$ thiobarbituric acid (TBA) and incubated at $100^{\circ} \mathrm{C}$ water bath for 20 minutes. After immediate chilling to the room temperature and centrifugation at $5,500 \mathrm{xg}$ (for $15 \mathrm{~min}$, the absorbance was read at $532 \mathrm{~nm}$ ). The results were then calculated according to the standard curve.

2.6. Statistical Analysis. Collected data were statistically evaluated by one-factorial ANOVA using StatSoft Statistica ${ }^{\circledR}$ Software (2013). The differences between treatments for all parameters were tested according to the following statistical model:

$$
\mathrm{Yij}=\mu+\mathrm{ai}+\mathrm{eij},
$$

where Yij is variance associated with parameter a; $\mu$ is the overall mean; ai is the treatment effect; and eij the error term. The individual measurements for chicken muscles were treated as the experimental units, and differences between treatments means were analyzed for significance $(p>0.05)$ using Tukey's test. The data are presented as an average value and accompanied by SEM (standard error).

\section{Results and Discussion}

3.1. Selenium Content. The effects of dietary Se supplementation of broiler chicken according to Se sources are presented in Figure 1. Natural Se content in various culinary parts of the chicken carcass differs from less than $10.00 \mu \mathrm{g} / 100 \mathrm{~g}$ muscle in the back, through an average $10.8 \mu \mathrm{g} / 100 \mathrm{~g}$ in both leg sets of muscles, up to $12.7-12.8 \mu \mathrm{g} / \mathrm{kg}$ for the breast muscles. Supplementation of the chicken diet with the selenized yeast and sodium selenite increased the muscle selenium level in all analyzed culinary parts of the chicken carcass. Ševčíková et al. [39] stated that increased content of selenium in broiler diets significantly increased its content in thigh muscle tissue, which is in accordance with our results. Selenium supplementation was more effective in the leg muscles $(18.5 \mu \mathrm{g} / \mathrm{kg}$ for inorganic Se and $20.3 \mu \mathrm{g} / 100 \mathrm{~g}$ for organic Se), compared with breast meat (max. $15.8 \mu \mathrm{g} / \mathrm{kg}$, with no apparent difference in the form of selenium). The organic form of selenium was deposited to a greater extent than the inorganic form. Previous studies $[39,40]$ are in agreement with the findings in the present study. This could probably be related to differences in metabolic pathways between organic and inorganic forms of selenium. According to [41], organic selenium is actively absorbed through an amino-acid transport mechanism, whereas inorganic selenium is passively absorbed from the intestine by a simple diffusion process.

Additionally, it was stated that frozen storage of all the culinary parts of the chicken carcass increased the selenium level in the muscles, which was mainly connected with the loss of moisture. During frozen storage, there are series of physical and biochemical changes, not only connecting with water loss, but also color change, lipid, and protein oxidation, which can influence the quality of frozen chicken meat [42].

3.2. Reactive Group Content. The effect of an organic and inorganic Se on the reactive group content in muscle proteins of the selected culinary parts of chicken during frozen storage is presented in Tables 2 and 3. Basically, three main reactive chemical groups creating physicochemical and functional properties of meat, i.e., carbonyl, sulfhydryl, and amine groups, were analyzed.

3.2.1. Carbonyl Groups. The process of carbonylation, recognized as one of the most remarkable chemical modification in oxidized proteins, can be promoted by reactive oxygen species $[12,14,43] \mathrm{CO}$ groups, which can be coupled of two tyrosyl radicals located in the same or different protein chains and could form dityrosine by formation of a covalent bond [44], which is usually related to the extent of oxidation processes occurred also during storage of meat and cause specific changes in the biological material. In the present study, CO-group content differed significantly ( $p>0.05)$ depending on the culinary parts of the chicken carcass being the highest in the outer and deep breast fillets, 


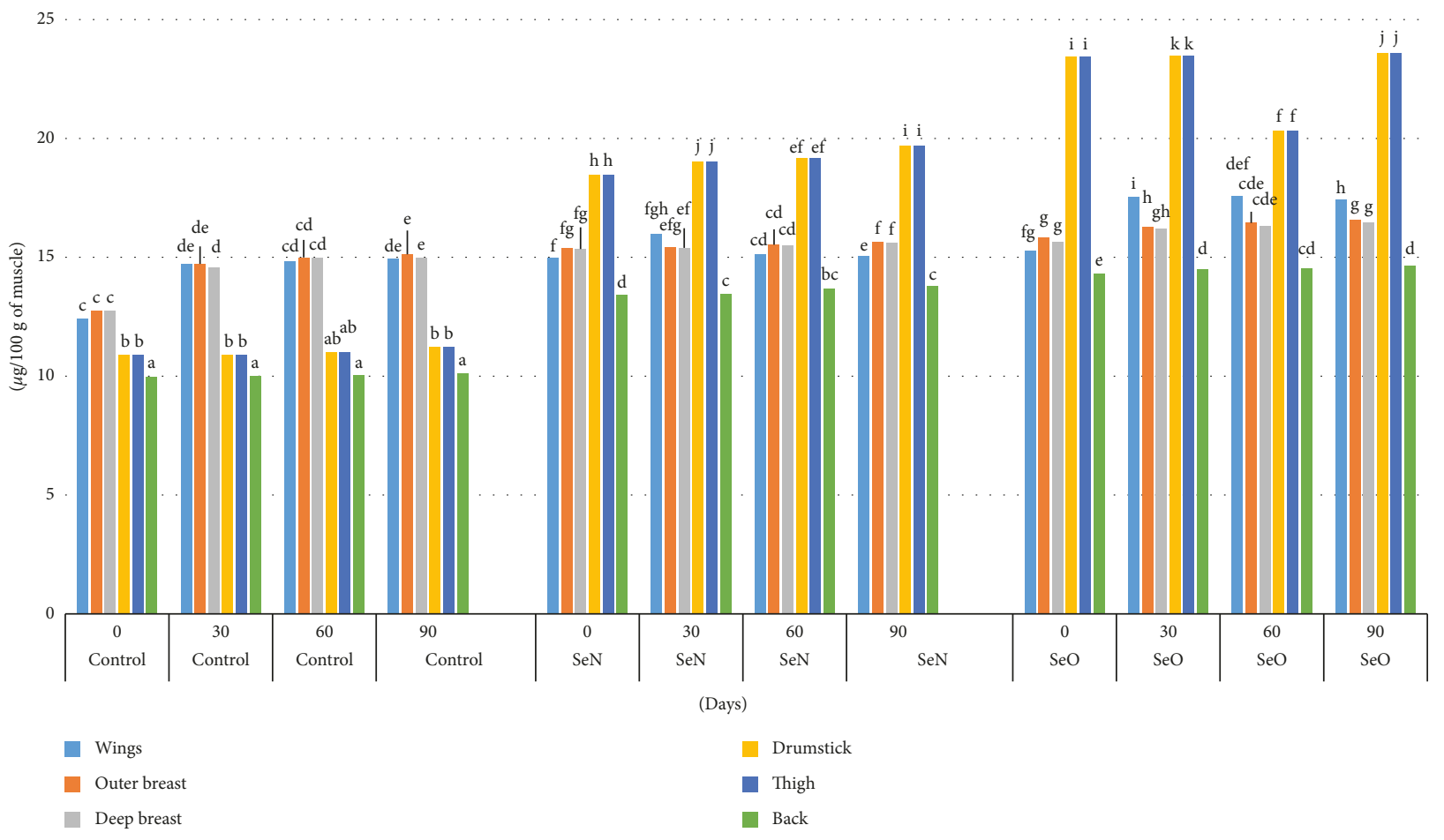

Figure 1: The content of selenium in selected culinary parts of chicken supplemented with organic and inorganic selenium.

as well as in wing muscles (app. $2.56 \mathrm{nM} / \mathrm{mg}$ protein), whereas the lowest in the back part $(1.64 \mathrm{nM} / \mathrm{mg}$ protein).

Frozen storage of the meat, both in the form of the whole carcass and separated parts, for 30 days resulted in the significant increase in the CO-group content. The most dynamic changes were observed in the back part, together with the leg components (thigh and drumstick). The oxidative changes continued to occur along with the increasing of the storage period. Se supplementation of the chicken diet significantly reduced the quantity of the $\mathrm{CO}$ groups in all analyzed culinary parts. Moreover, the effect was much stronger in the case of an organic Se supplementation comparing to the inorganic form of diet enrichment. Organic Se was effective in reducing the extent of the group formation during the first 30 days of frozen storage in the majority of the analyzed culinary parts of the chicken carcass, except thigh and back. In case of drumstick, the formation of CO groups was blocked totally in meat obtained from the chicken supplemented with selenized yeasts, even up to 90 days of storage at $-18^{\circ} \mathrm{C}$. This could be explained by the active system of an antioxidative protection within the drumstick muscles. Inorganic Se was able to slow down the oxidation processes measured by the content of the $\mathrm{CO}$ groups only in case of deep breast and back muscles during the first 30 days of storage. Anyway, the extent of protein oxidation was smaller compared to the control samples in the case of all analyzed chicken culinary parts. The increase in the formation of the $\mathrm{CO}$ groups in the proteins during frozen storage coupled with the freeze-thaw cycles was previously stated by Giulivi et al. [45] and connected with increasing tyrosyl radical formation effected in dityrosine generation after isomerization, diradical reaction, and enolization. Xia et al. [46] reported that higher CO content was produced due to protein oxidation, which could be accelerated by multiple freeze-thaw cycles.

3.2.2. Sulfhydryl Groups. The presence of the free thiol groups, a sulfhydryl group in meat proteins is mostly responsible for the gelling properties, as well as flavor formation during thermal treatment. Generally, breast muscles were characterized by a lower content of the SH groups than leg, back, and wing muscles, which can be connected with the muscle fiber type and metabolism. The breast muscle is composed mostly of white muscle fibers, whilst the othermentioned muscles are formed mostly of red or mixed types of fibers. The freezing technology cased the significant $(p>0.05)$ loss in the free $\mathrm{SH}$ groups of myofibrillar proteins extracted from chicken meat from various culinary parts of the carcass. The biggest decrease in the free sulfhydryl group concentration after 30 days of freezing storage was observed in drumstick muscles, in which the loss of $\mathrm{SH}$ reached about $21 \mathrm{nM} / \mathrm{mg}$ proteins. Prolongation of the storage in freezing conditions resulted in further decrease in free sulfhydryl groups content in all analyzed groups of muscles. Application of Se to the chicken diet resulted in the lower number of free sulfhydryl concentration in relation to the control, and the only exception was observed for an inorganic form of selenium in case of thigh and back. However, the inorganic Se addition was not able to preserve the initial number of free $\mathrm{SH}$ in chicken wings and outer breast, and it had a protective action on the groups during first 30 days of frozen storage. Organic Se was effective in protection of the sulfhydryl groups against oxidation in the first period of 


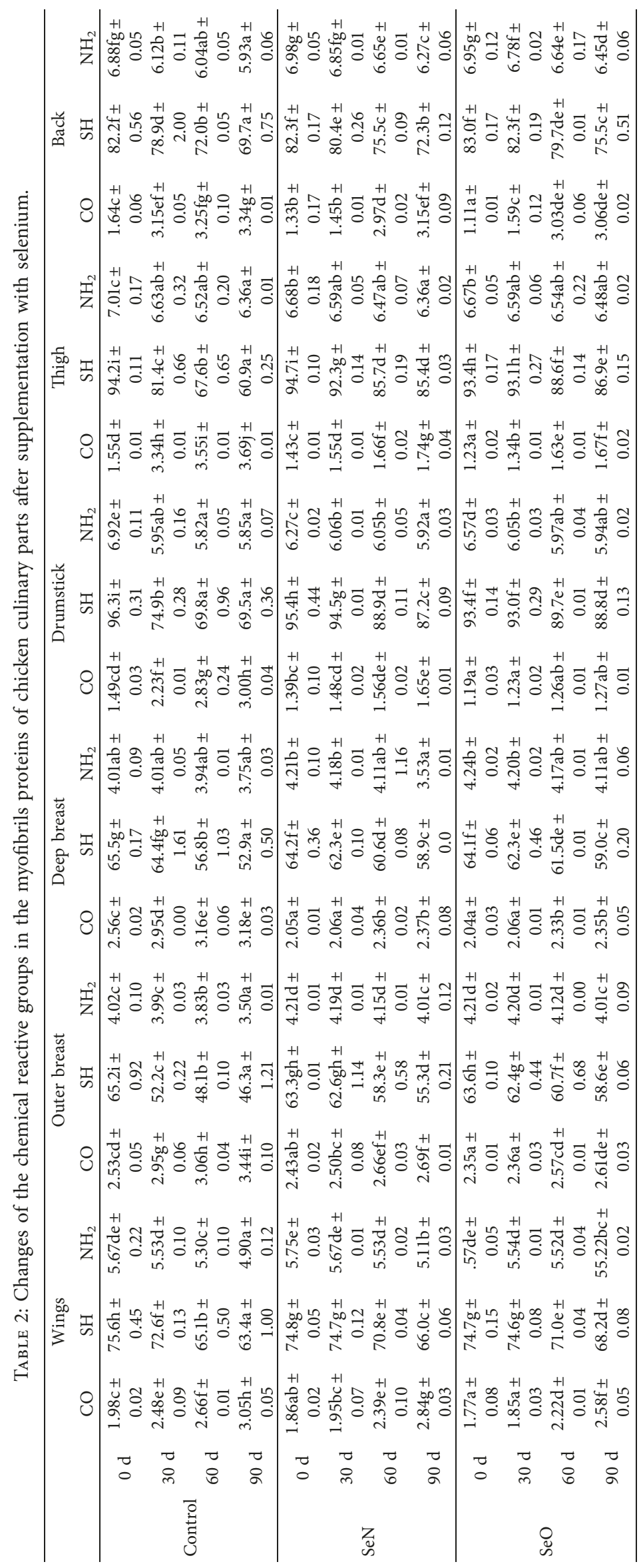


TABLE 3: Statistical significance $p>0.05$ for the content of the chemical reactive groups in the myofibrils proteins, antioxidative potential, and selenium content of chicken culinary parts after supplementation with selenium during frozen storage.

\begin{tabular}{|c|c|c|c|c|c|c|c|c|c|}
\hline & & $\mathrm{CO}$ & $\mathrm{SH}$ & $\mathrm{NH}_{2}$ & ABTS & $\mathrm{DPPH}$ & FRAP & TBARS & $\mathrm{Se}$ \\
\hline \multirow{3}{*}{ Wings } & Additive & 0.00 & 0.00 & 0.00 & 0.00 & 0.00 & 0.00 & 0.00 & 0.00 \\
\hline & Time of storage & 0.00 & 0.00 & 0.00 & 0.00 & 0.00 & 0.00 & 0.00 & 0.00 \\
\hline & Additive $*$ time of storage & 0.00 & 0.00 & 0.04 & 0.00 & 0.00 & 0.00 & 0.00 & 0.03 \\
\hline \multirow{3}{*}{ Outer breast } & Additive & 0.00 & 0.00 & 0.00 & 0.00 & 0.00 & 0.00 & 0.00 & 0.00 \\
\hline & Time of storage & 0.00 & 0.00 & 0.00 & 0.00 & 0.00 & 0.00 & 0.00 & 0.00 \\
\hline & Additive $*$ time of storage & 0.00 & 0.00 & 0.00 & 0.00 & 0.00 & 0.00 & 0.13 & 0.00 \\
\hline \multirow{3}{*}{ Inner breast } & Additive & 0.00 & 0.00 & 0.20 & 0.00 & 0.00 & 0.00 & 0.00 & 0.00 \\
\hline & Time of storage & 0.00 & 0.00 & 0.44 & 0.00 & 0.00 & 0.00 & 0.00 & 0.00 \\
\hline & Additive $*$ time of storage & 0.00 & 0.00 & 0.36 & 0.00 & 0.00 & 0.00 & 0.00 & 0.00 \\
\hline \multirow{3}{*}{ Drumstick } & Additive & 0.00 & 0.00 & 0.01 & 0.00 & 0.00 & 0.00 & 0.00 & 0.00 \\
\hline & Time of storage & 0.00 & 0.00 & 0.00 & 0.00 & 0.00 & 0.00 & 0.00 & 0.41 \\
\hline & Additive $*$ time of storage & 0.00 & 0.00 & 0.00 & 0.00 & 0.00 & 0.00 & 0.00 & 0.45 \\
\hline \multirow{3}{*}{ Thigh } & Additive & 0.00 & 0.00 & 0.24 & 0.00 & 0.00 & 0.00 & 0.00 & 0.00 \\
\hline & Time of storage & 0.00 & 0.00 & 0.00 & 0.00 & 0.00 & 0.00 & 0.00 & 0.41 \\
\hline & Additive $*$ time of storage & 0.00 & 0.00 & 0.12 & 0.00 & 0.00 & 0.00 & 0.00 & 0.45 \\
\hline \multirow{3}{*}{ Back } & Additive & 0.00 & 0.00 & 0.00 & 0.00 & 0.00 & 0.00 & 0.00 & 0.00 \\
\hline & Time of storage & 0.00 & 0.00 & 0.00 & 0.00 & 0.00 & 0.00 & 0.00 & 0.00 \\
\hline & Additive $*$ time of storage & 0.00 & 0.00 & 0.00 & 0.00 & 0.00 & 0.00 & 0.00 & 0.04 \\
\hline \multirow{3}{*}{ Fresh } & Culinary part & 0.00 & 0.00 & 0.00 & 0.00 & 0.00 & 0.00 & 0.00 & 0.00 \\
\hline & Additive & 0.00 & 0.00 & 0.06 & 0.00 & 0.00 & 0.00 & 0.00 & 0.00 \\
\hline & Culinary part $*$ additive & 0.00 & 0.00 & 0.00 & 0.00 & 0.00 & 0.00 & 0.00 & 0.00 \\
\hline \multirow{3}{*}{$30 \mathrm{~d}$} & Culinary part & 0.00 & 0.00 & 0.00 & 0.00 & 0.00 & 0.00 & 0.00 & 0.00 \\
\hline & Additive & 0.00 & 0.00 & 0.12 & 0.00 & 0.00 & 0.00 & 0.00 & 0.00 \\
\hline & Culinary part $*$ additive & 0.00 & 0.00 & 0.05 & 0.00 & 0.00 & 0.00 & 0.00 & 0.00 \\
\hline \multirow{3}{*}{$60 d$} & Culinary part & 0.00 & 0.00 & 0.00 & 0.00 & 0.00 & 0.00 & 0.00 & 0.00 \\
\hline & Additive & 0.00 & 0.00 & 0.00 & 0.00 & 0.00 & 0.00 & 0.00 & 0.00 \\
\hline & Culinary part $*$ additive & 0.00 & 0.00 & 0.05 & 0.00 & 0.00 & 0.00 & 0.00 & 0.00 \\
\hline \multirow{3}{*}{$90 \mathrm{~d}$} & Culinary part & 0.00 & 0.00 & 0.00 & 0.00 & 0.00 & 0.00 & 0.00 & 0.00 \\
\hline & Additive & 0.00 & 0.00 & 0.00 & 0.00 & 0.00 & 0.00 & 0.00 & 0.00 \\
\hline & Culinary part $*$ additive & 0.00 & 0.00 & 0.00 & 0.00 & 0.00 & 0.00 & 0.00 & 0.00 \\
\hline
\end{tabular}

frozen storage in most of the muscles, and the only exception was breast muscles. Extended storage up to 90 days tends to further loss in the free $\mathrm{SH}$ groups mostly due to the formation of S-S double bonds caused by the protein oxidation, especially in cysteine residues [47].

3.2.3. Free Amino Groups. The free amino group content of chicken myofibrillar proteins differed amongst the analyzed type of culinary parts (Tables 2 and 3). Lower $\mathrm{NH}_{2}$ group concentration was measured in both breast muscles (around $4.0 \mu \mathrm{M} / \mathrm{mg}$ protein), whilst the highest in thigh and drumstick (average of $6.9-7.0 \mu \mathrm{M} / \mathrm{mg}$ protein). The free $\mathrm{NH}_{2}$ groups usually come from lysine-containing side chains [48]. The basic level of free amine group content in the control chicken meat in the study was generally lower than stated by [48], but the results collected during frozen storage of the meat were consistent with the cited authors. In both studies, the decrease in the total free $\mathrm{NH}_{2}$ group content was observed, except for the deep breast muscles. This trend can be explained by the oxidation processes that, among other changes, cause the deamination of the $\varepsilon-\mathrm{NH}_{2}$ groups of lysine residues to carbonyls, which then react with available amine groups, leading to a further reduction in the free amine content [49]. Selenium application in the chicken diet resulted in the higher availability of free amine groups in the breast muscles; however, lower content of free $\mathrm{NH}_{2}$ in the leg muscles. The Se applied to the chicken fodder, despite the form of the microelement, significantly slowed down the oxidative changes in outer and deep breast muscle up to 60 and 30 days, respectively. In general, the extent of decreasing the free amine group in the experimental groups was lower throughout the whole storage period (with an exception of a deep breast).

3.3. Total Antioxidative Capacity. The TAC is the capacity of antioxidants required to reduce oxidants, and its measurement provides useful information about the overall antioxidant status. When antioxidant defense systems are weakened, body cells and tissues become more susceptible to develop dysfunction and that is why maintenance of adequate antioxidant levels is important [50]. The effect of selenium in poultry nutrition is associated with its participation in maintaining the antioxidant system, so measurement of TAC is a useful biomarker for evaluating the Se antioxidative role. The following assays ABTS and DPPH radical scavenging methods, and FRAP have been frequently used to estimate antioxidant capacities because each assay involves different chemicals and may reflect different aspects of their antioxidant properties [51]. The results of the TAC collected in the present study are shown in Tables 3 and 4. 


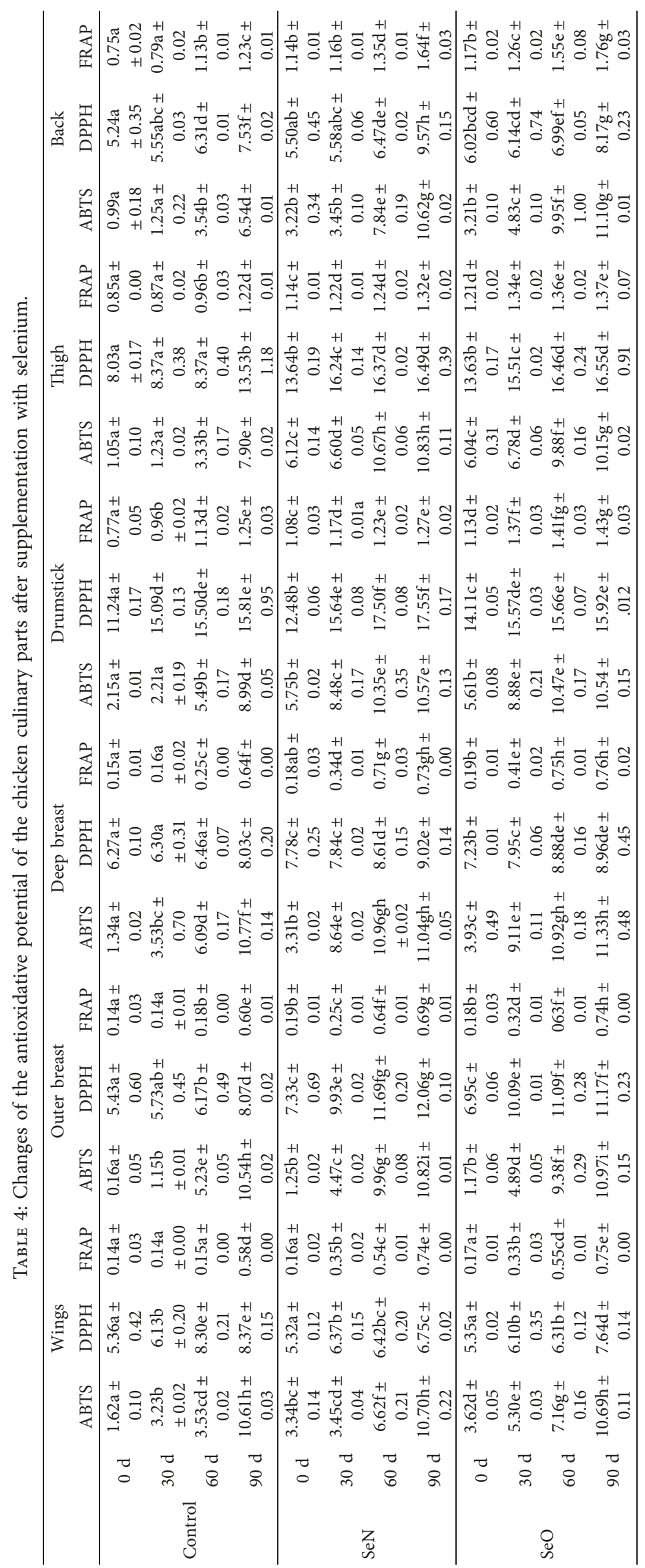


3.3.1. ABTS+ Assay. The capacity of different muscles of the chicken culinary parts to scavenge a synthetic free radical ABTS is presented in Table 4. The lowest antioxidative potential measured by the ABTS methodology was analyzed for the outer breast muscles (musculus pectoralis superficialis) $(0.16 \mu \mathrm{M}$ Trolox $/ \mathrm{g})$, whereas the deep breast muscles (musculus pectoralis profundus) had significantly higher free radical scavenging ability $(1.34 \mu \mathrm{M}$ Trolox/g). The highest values were analyzed for drumstick muscles. The results are not in agreement with [52] who claimed higher antioxidative potential of the breast muscles. The capacity of the muscles to remove the free radical tended to increase during frozen storage of the biological material, reaching the highest values after 90 days of the storage in all culinary parts. This can be associated with the loss of moisture due to evaporation, as well as structural changes in the proteins and lipids due to oxidation processes. The application of selenium to the chicken diet increases the ability of the muscles to scavenge the synthetic free radical ABTS significantly between 2.0 and 8.0 times for the wings and outer breast (sodium selenite) muscles. During the frozen storage of the meat, the ABTS scavenge ability increases similarly to the control sample.

3.3.2. DPPH+ Assay. The antioxidative power of the chicken culinary parts measured during the frozen storage period followed the same trend as described for the ABTS. However, the extend of the changes was much lower. Generally, the set of the leg muscles, both drumstick, and thigh, was characterized by significantly higher DPPH free radical scavenging ability than the rest of the analyzed muscles. The application of Se into the chicken diet increases the meat ability to scavenge the free radical DPPH, as selenium is known from its antioxidative properties. During frozen storage, the DPPH removal ability increased in all analyzed sets of the chicken muscles, indicating that selenium is more stable in the muscles and significantly impaired the antioxidative potential of the biological material.

3.3.3. FRAP Assay. The ability of the chicken myofibrillar proteins extracted from the leg and back muscles to reduce the $\mathrm{Fe}^{3+}$ to $\mathrm{Fe}^{2+}$ was almost seven times higher than that analyzed for the wings and breast muscles. No changes in the iron reduction ability during the first 30 days of frozen storage were observed for all analyzed muscle types. Longer storage at freezing temperature resulted in the significant increase in the measured ability, which was probably connected with the loss of moisture, as for the ABTS and DPPH free radicals scavenging ability. Selenium application in the chicken diet did not significantly change the FRAP values for the wings and breast muscles; however, a significant increase in the iron reduction ability was noted for both sets of the leg muscles, and back muscles, which can be related to the higher deposition of the selenium in the part richer in lipids.

3.4. The Extend of the Oxidation Processes by 2-Thiobarbituric Acid Reactive Substances Content. Malondialdehyde (MDA) is one of the secondary products of lipid oxidation, which has long been considered as an index of oxidative rancidity in various foodstuffs. Among all the methods proposed for assessing MDA, the 2-thiobarbituric acid (TBARS) has been widely adopted as a sensitive assay for lipid oxidation in animal tissues. In practice, meat is stored and cooked before consumption. These processes promote degradation of meat lipid fraction $[42,53]$.

Culinary parts of the chicken carcasses were characterized by the different extents of the lipid oxidation, both in the selenium-supplemented chickens and also control animals (Figure 2). The lowest TBARS values were stated for the breast muscles, followed by the wings and the leg and back muscles, which was associated with the total lipid content. Frozen storage of the culinary parts increased TBARS values for all analyzed meat types significantly, but the highest increase was noted for the back muscles (from around $0.45 \mathrm{mg} / \mathrm{kg}$ for the fresh samples to almost $2.50 \mathrm{mg} / \mathrm{kg}$ for the samples kept in the freezer for 90 days). The deteriorative effects of long-frozen storage on the quality of meat were previously reported [42]. Higher intensity of the lipid oxidation during frozen storage was also noted for the leg muscles comparing to breast, which was also observed by the other authors [42,53-56]. This was caused by higher lipid, haem proteins and microsomal enzyme content. Opposite results were published by Malczyk [57], who found higher TBARS values in the breast muscles, which was related to higher content of the unsaturated phospholipids. Application of the selenium form in the chicken diet caused a significant reduction in the lipid oxidation and formation of the derivatives in all analyzed muscle types. The extent of the oxidation processes during frozen storage slowed down in most of the cases (except the back) up to 30 days. The back muscles went through oxidation very easily mostly due to lack of the antioxidant deposition, size of the muscles, lipid content, and also the location in the carcass.

\section{Conclusions}

Chicken carcass is a complex set of different muscles and lipid types/classes, which are unevenly deposited in specific parts of the bird's body. This causes significant differences in the susceptibility on the oxidation processes shaping the quality and shelf-life of the product. Postmortem processes, mechanical treatment (cutting up the carcasses into the culinary parts, deboning, grinding), and storage conditions influence the oxidative potential and stability of the edible parts of the carcass.

The least changes in the protein and lipid caused by oxidation processes during frozen storage were analyzed in the outer (pectoralis major m.) and deep (pectoralis minor m.) breasts, followed by the wing muscles. The leg (thigh and drumstick) together with back muscles was more susceptible especially to lipid changes and less to protein oxidation. Generally, most of the chicken culinary parts, except back, can be stored at the freezing conditions up to 30 days without apparent deteriorative changes in protein and lipid fractions. Longer storage could be only recommended to breast fillets. 


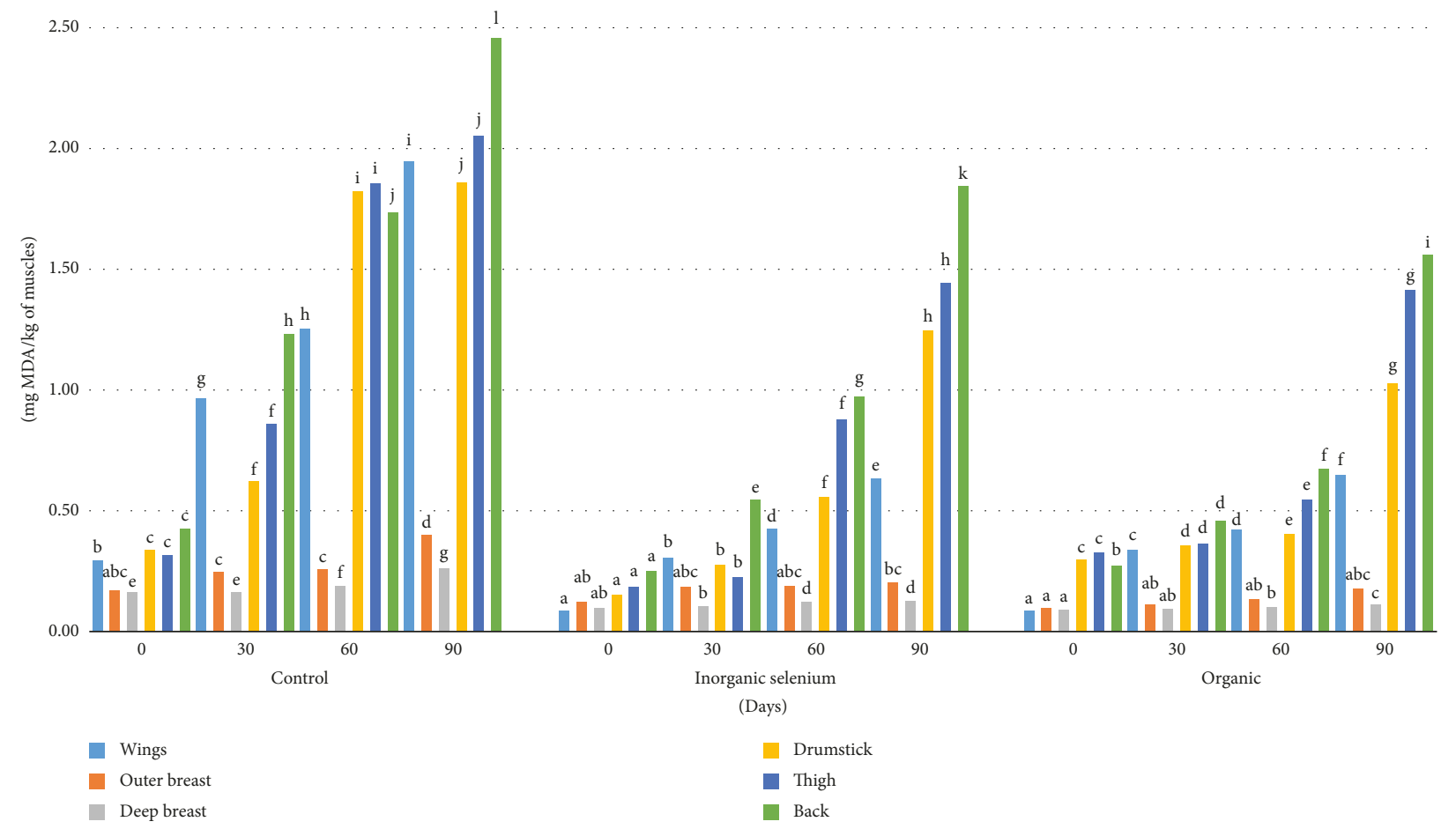

FIGURE 2: Changes in the thiobarbituric acid reactive substances during frozen storage of the culinary parts of chicken supplemented with selenium.

Selenium supplementation of the chicken diet significantly reduced the oxidative changes in the most important chemical reactive groups of the muscle myofibrillar proteins in all analyzed culinary parts. Both forms of selenium, organic and inorganic, were able to slow down the oxidation processes during the first 30 days of the frozen storage of the meat. The effect was much stronger in case of an organic selenium supplementation comparing to inorganic form of diet enrichment. Summing up, the selenium application in the chicken broiler diet can successfully impart the shelf-life of the separated culinary parts of the chicken carcass.

\section{Data Availability}

The data used to support the findings of this study are included within the article.

\section{Conflicts of Interest}

The authors declare that there are no conflicts of interest regarding the publication of this article.

\section{Acknowledgments}

The study was supported by Polish Ministry of Science, project no. N N312 253938, financed by the National Science Centre, Poland. The project was supported by Wroclaw Centre of Biotechnology, The Leading National Research Centre (KNOW), for the years 2014-2018. We would like to acknowledge the Department of Animal Nutrition and Feed Quality, Wroclaw University of Environmental and Life
Sciences, 38C Chełmońskiego Str., 51-630 Wroclaw, Poland, for carrying out the chicken feeding study.

\section{References}

[1] V. Lobo, A. Patil, A. Phatak, and N. Chandra, "Free radicals, antioxidants and functional foods: Impact on human health," Pharmacognosy Reviews, vol. 4, no. 8, pp. 118-126, 2010.

[2] G. Pizzino, N. Irrera, M. Cucinotta et al., "Oxidative stress: Harms and benefits for human Health," Oxidative Medicine and Cellular Longevity, vol. 2017, Article ID 8416763, 13 pages, 2017.

[3] L. Cortinas, A. Barroeta, C. Villaverde, J. Galobart, F. Guardiola, and M. D. Baucells, "Influence of the dietary polyunsaturation level on chicken meat quality: lipid oxidation," Poultry Science, vol. 84, no. 1, pp. 48-55, 2005.

[4] R. S. Filgueras, P. Gatellier, R. C. Zambiazi, and V. SanteLhoutellier, "Effect of frozen storage duration and cooking on physical and oxidative changes in M. Gastrocnemius pars interna and M. Iliofiburalis of Rhea americana," Meat Science, vol. 88, no. 4, pp. 645-651, 2011.

[5] Y. Z. Fang, S. Yang, and G. Wu, "Free radicals, antioxidants, and nutrition," Nutrition, vol. 18, no. 10, pp. 872-879, 2002.

[6] A. C. Barroeta, "Nutritive value of poultry meat: relationship between vitamin E and PUFA," World's Poultry Science Journal, vol. 63, no. 2, pp. 277-284, 2007.

[7] J. Stangierski and G. Lesnierowski, "Nutritional and healthpromoting aspects of poultry meat and its processed products," World's Poultry Science Journal, vol. 71, no. 1, pp. 71-82, 2015.

[8] J. Juskiewicz, J. Jankowski, H. Zielinski et al., "The fatty acid profile and oxidative stability of meat from turkeys fed diets enriched with n-3 polyunsaturated fatty acids and dried fruit 
pomaces as a source of polyphenols," PLoS One, vol. 12, no. 1, Article ID e0170074, 2017.

[9] A. Tres, N. Magrinyà, R. Bou, F. Guardiola, C. D. Nuchi, and R. Codony, "Impact of the oxidative quality of fish oils in feeds on the composition and oxidative stability of chicken and rabbit meat," Animal Feed Science and Technology, vol. 196, pp. 76-87, 2014.

[10] C. Castillo, V. Pereira, Á. Abuelo, and J. Hernández, "Effect of supplementation with antioxidants on the quality of bovine milk and meat production," The Scientific World Journal, vol. 2013, Article ID 616098, 8 pages, 2013.

[11] O. P. Soladoye, M. L. Juárez, J. L. Aalhus, P. Shand, and M. Estévez, "Protein oxidation in processed meat: mechanisms and potential implications on human health," Comprehensive Reviews in Food Science and Food Safety, vol. 14, no. 2, pp. 106-122, 2015.

[12] M. Estevez, "Protein carbonyls in meat systems: a review," Meat Science, vol. 89, no. 3, pp. 259-279, 2011.

[13] J. Jiang, X. Tang, Y. Xue, G. Lin, and Y. L. Xiong, "Dietary linseed oil supplemented with organic selenium improved the fatty acid nutritional profile, muscular selenium deposition, water retention, and tenderness of fresh pork," Meat Science, vol. 131, pp. 99-106, 2017.

[14] M. Estévez, S. Ventanas, and R. Cava, "Protein oxidation in frankfurters with increasing levels of added rosemary essential oil: effect on color and texture deterioration," Journal of Food Science, vol. 70, no. 7, pp. c427-c432, 2005.

[15] R. M. Delles, Y. L. Xiong, A. D. True, T. Ao, and K. A. Dawson, "Dietary antioxidant supplementation enhances lipid and protein oxidative stability of chicken broiler meat through promotion of antioxidant enzyme activity," Poultry Science, vol. 93, no. 6, pp. 1561-1570, 2014.

[16] R. M. Delles, Y. L. Xiong, A. D. True, T. Ao, and K. A. Dawson, "Augmentation of water-holding and textural properties of breast meat from oxidatively stressed broilers by dietary antioxidant regimens," British Poultry Science, vol. 56, no. 3, pp. 304-314, 2015.

[17] M. M. Farouk and J. E. Swan, "Effect of rigor temperature and frozen storage on functional properties of hot-boned manufacturing beef," Meat Science, vol. 49, no. 2, pp. 233247, 1998.

[18] B. C. Shanks, D. M. Wulf, and R. J. Maddock, "Technical note: the effect of freezing on Warner-Bratzler shear force values of beef longissimus steaks across several postmortem aging periods," Journal of Animal Science, vol. 80, no. 8, pp. 2122-2125, 2002.

[19] Z. Pietrasik and J. A. Janz, "Influence of freezing and thawing on the hydration characteristics, quality, and consumer acceptance of whole muscle beef injected with solutions of salt and phosphate," Meat Science, vol. 81, no. 3, pp. 523-532, 2009.

[20] E. Muela, C. Sanudo, M. M. Campo, I. Medel, and J. A. Beltran, "Effect of freezing method and frozen storage duration on lamb sensory quality," Meat Science, vol. 90, no. 1, pp. 209-215, 2012.

[21] J. F. Stika, Y. L. Xiong, S. P. Suman, S. P. Blanchard, and W. G. Moody, "Frozen storage stability of antioxidant-treated raw restructured beef steaks made from mature cows," Meat Science, vol. 77, no. 4, pp. 562-569, 2007.

[22] L. V. Papp, A. Holmgren, and K. K. Khanna, "Selenium and selenoproteins in health and disease," Antioxidants and Redox Signaling, vol. 12, no. 7, pp. 793-795, 2010.

[23] M. T. Zimmerman, C. A. Bayse, R. R. Ramoutar, and J. L. Brumaghim, "Sulfur and selenium antioxidants: challenging radical scavenging mechanisms and developing structure-activity relationships based on metal binding," Journal of Inorganic Biochemistry, vol. 145, pp. 30-40, 2015.

[24] E. Mukwevho, Z. Ferreira, and A. Ayeleso, "Potential role of sulfur-containing antioxidant systems in highly oxidative environments," Molecules, vol. 19, no. 12, pp. 19376-19389, 2014.

[25] D. C. Mahan, M. Azain, T. D. Crenshaw et al., "Supplementation of organic and inorganic selenium to diets using grains grown in various regions of the United States with differing natural Se concentrations and fed to grower-finisher swine," Journal of Animal Science, vol. 92, no. 11, pp. 49914997, 2014.

[26] J. N. De Almeida, G. R. Dos Santos, F. M. Beteto et al., "Dietary supplementation of chelated selenium and broiler chicken meat quality (in Portuguese)," Semina: Ciências Agrárias, vol. 33, no. 2, pp. 3117-3122, 2012.

[27] S. V. Rao, B. Prakash, M. V. Raju, A. K. Panda, S. Poonam, and O. K. Murthy, "Effect of supplementing organic selenium on performance, carcass traits, oxidative parameters and immune responses in commercial broiler chickens," AsianAustralasian Journal of Animal Sciences, vol. 26, no. 2, pp. 247-252, 2013.

[28] S. L. da Silva, C. Marangoni, D. S. Brum et al., "Effect of dietary olive leaves on the lipid and protein oxidation and bacterial safety of chicken hamburgers during frozen storage," International Food Research Journal, vol. 25, no. 1, pp. 383391, 2018.

[29] A. C. Pappas, E. Zoidis, G. Papadomichelakis, and K. Fegeros, "Supranutritional selenium level affects fatty acid composition and oxidative stability of chicken breast muscle tissue," Journal of Animal Physiology and Animal Nutrition, vol. 96, no. 3, pp. 385-394, 2012.

[30] EFSA Panel on Additives and Products or Substances used in Animal Feed, "Scientific opinion on safety and efficacy of selenium in the form of organic compounds produced by the selenium-enriched yeast Saccharomyces cerevisiae NCYC R646 (Selmax 1000/2000) as feed additive for all species," EFSA Journal, vol. 10, no. 7, p. 2778, 2012.

[31] W. Kopec, A. Wiliczkiewicz, D. Jamroz et al., "Antioxidant status of turkey breast meat and blood after feeding a diet enriched with histidine," Poultry Science, vol. 95, no. 1, pp. 53-61, 2016.

[32] S. Srinivasan, Y. L. Xiong, and E. A. Decker, "Inhibition of protein and lipid oxidation in beef heart surimi-like material by antioxidants and combinations of $\mathrm{pH}, \mathrm{NaCl}$, and buffer type in the washing media," Journal of Agricultural and Food Chemistry, vol. 44, no. 1, pp. 119-125, 1996.

[33] R. L. Levine, D. Garland, C. N. Oliver et al., "Determination of carbonyl content in oxidatively modified proteins," in Methods in Enzymology, pp. 464-478, Academic Press, Cambridge, MA, USA, 1990.

[34] J. L. Carty, R. Bevan, H. Waller et al., "The effects of vitamin c supplementation on protein oxidation in healthy volunteers," Biochemical and Biophysical Research Communications, vol. 273, no. 2, pp. 729-735, 2000.

[35] A. Aitken and M. Learmonth, "Estimation of disulfide bonds using Ellman's reagent," in The Protein Protocols Handbook, J. M. Walker, Ed., pp. 487-488, Humana Press, Totowa, NJ, USA, 1996.

[36] P. Cayot and G. Tainturier, "The quantification of protein amino groups by the trinitrobenzenesulfonic acid method: a reexamination," Analytical Biochemistry, vol. 249, no. 2, pp. 184-200, 1997. 
[37] M. Korzeniowska, B. Króliczewska, and W. Kopeć, “Carbonyl and sulfhydryl groups of chicken meat proteins after dietary modulation with selenium," Open Chemistry, vol. 13, no. 1, 2015.

[38] L. Mei, G. L. Cromwell, A. D. Crum, and E. A. Decker, "Influence of dietary beta-alanine and histidine on the oxidative stability of pork," Meat Science, vol. 49, no. 1, pp. 55-64, 1998.

[39] S. Ševčíková, M. Skřivan, G. Dlouhá, and M. Koucký, “The effect of selenium source on the performance and meat quality of broiler chickens," Czech Journal of Animal Science, vol. 51, no. 10, pp. 449-45, 2006.

[40] M. Skrivan, M. Marounek, G. Dlouha, and S. Sevcikova, "Dietary selenium increases vitamin E contents of egg yolk and chicken meat," British Poultry Science, vol. 49, no. 4, pp. 482-486, 2008.

[41] S. Wolffram, B. Berger, B. Grenacher, and E. Scharrer, "Transport of selenoamino acids and their sulfur analogues across the intestinal brush border membrane of pigs," Journal of Nutrition, vol. 119, no. 5, pp. 706-712, 1989.

[42] A. Soyer, B. Özalp, Ü. Dalmış, and V. Bilgin, "Effects of freezing temperature and duration of frozen storage on lipid and protein oxidation in chicken meat," Food Chemistry, vol. 120, no. 4, pp. 1025-1030, 2010.

[43] Y. J. Suzuki, M. Carini, and D. A. Butterfield, "Protein carbonylation," Antioxidants and Redox Signaling, vol. 12, no. 3, pp. 323-325, 2010.

[44] S. Saeed, D. Gillies, G. Wagner, and N. K. Howell, "ESR and NMR spectroscopy studies on protein oxidation and formation of dityrosine in emulsions containing oxidised methyl linoleate," Food and Chemical Toxicology, vol. 44, no. 8, pp. 1385-1392, 2006.

[45] C. Giulivi and K. J. Davies, "Mechanism of the formation and proteolytic release of $\mathrm{H} 2 \mathrm{O} 2$-induced dityrosine and tyrosine oxidation products in hemoglobin and red blood cells," Journal of Biological Chemistry, vol. 276, no. 26, pp. 2412924136, 2001.

[46] X. Xia, B. Kong, Q. Liu, and J. Liu, "Physicochemical change and protein oxidation in porcine longissimus dorsi as influenced by different freeze-thaw cycles," Meat Science, vol. 83, no. 2, pp. 239-245, 2009.

[47] G. Nieto, S. Jongberg, M. L. Andersen, and L. H. Skibsted, "Thiol oxidation and protein cross-link formation during chill storage of pork patties added essential oil of oregano, rosemary, or garlic," Meat Science, vol. 95, no. 2, pp. 177-184, 2013.

[48] E. Sehanobish, M. D. Chacon-Verdu, A. Sanchez-Amat, and V. L. Davidson, "Roles of active site residues in LodA, a cysteine tryptophylquinone dependent epsilon-lysine oxidase," Archives of Biochemistry and Biophysics, vol. 579, pp. 26-32, 2015.

[49] Y. Cao and Y. L. Xiong, "Chlorogenic acid-mediated gel formation of oxidatively stressed myofibrillar protein," Food Chemistry, vol. 180, pp. 235-243, 2015.

[50] C. Kusano and B. Ferrari, "Total antioxidant capacity: a biomarker in biomedical and nutritional studies," Journal of Cell and Molecular Biology, vol. 7, no. 1, pp. 1-15, 2008.

[51] A. Serpen, V. Gökmen, and V. Fogliano, "Total antioxidant capacities of raw and cooked meats," Meat Science, vol. 90, no. 1, pp. 60-65, 2012.

[52] G. Sacchetti, C. Di Mattia, P. Pittia, and G. Martino, "Application of a radical scavenging activity test to measure the total antioxidant activity of poultry meat," Meat Science, vol. 80, no. 4, pp. 1081-1085, 2008.
[53] J. Pikul, D. E. Leszczynski, P. J. Bechtel, and F. A. Kummerow, "Effects of frozen storage and cooking on lipid oxidation in chicken meat," Journal of Food Science, vol. 49, no. 3, pp. 838-843, 1984.

[54] S. Ali, W. Zhang, N. Rajput, M. A. Khan, C.-B. Li, and G.-H. Zhou, "Effect of multiple freeze-thaw cycles on the quality of chicken breast meat," Food Chemistry, vol. 173, pp. 808-814, 2015.

[55] S. Eymard, C. P. Baron, and C. Jacobsen, "Oxidation of lipid and protein in horse mackerel (Trachurus trachurus) mince and washed minces during processing and storage," Food Chemistry, vol. 114, no. 1, pp. 57-65, 2009.

[56] Z. M. Abdel-Kader, "Lipid oxidation in chicken as affected by cooking and frozen storage," Food/Nahrung, vol. 40, no. 1, pp. 21-24, 1996.

[57] E. Malczyk, "Influence of feeding system on oxidative processes occurring in chicken meat during refrigeration storage," Żywność Nauka Technologia Jakość, vol. 3, pp. 136-150, 1999. 

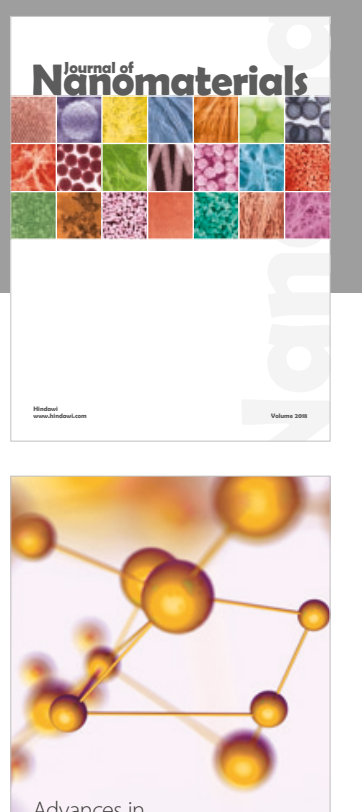

Physical Chemistry
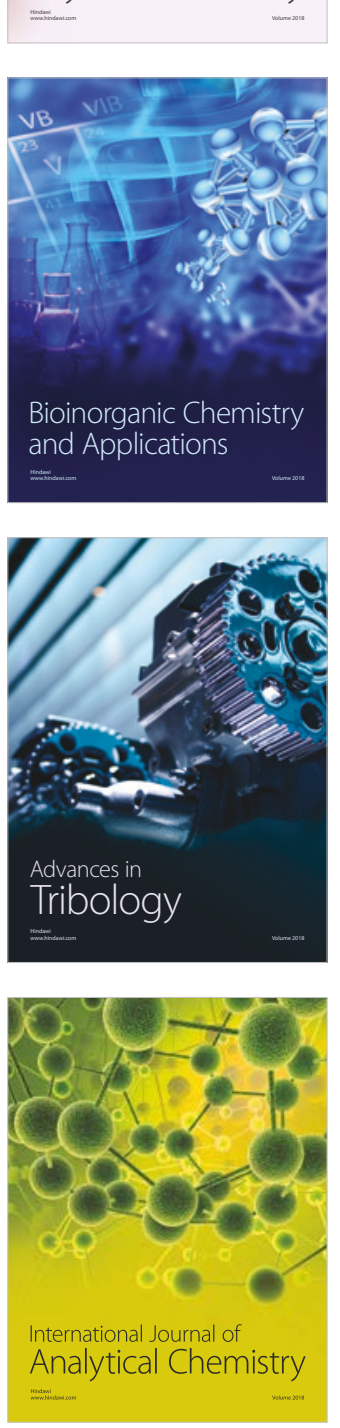

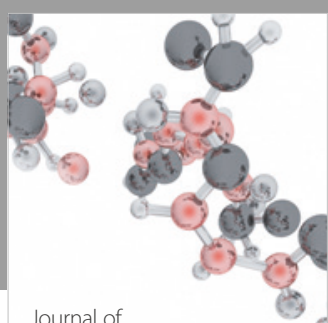

Analytical Methods

in Chemistry

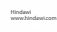

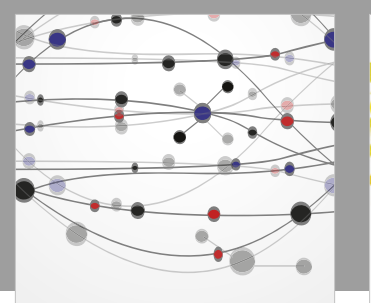

The Scientific World Journal

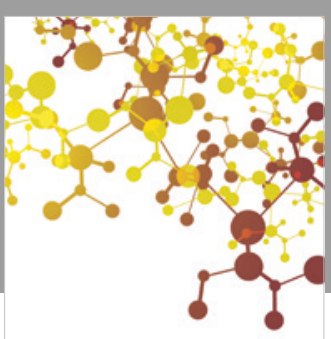

Journal of

Applied Chemistry
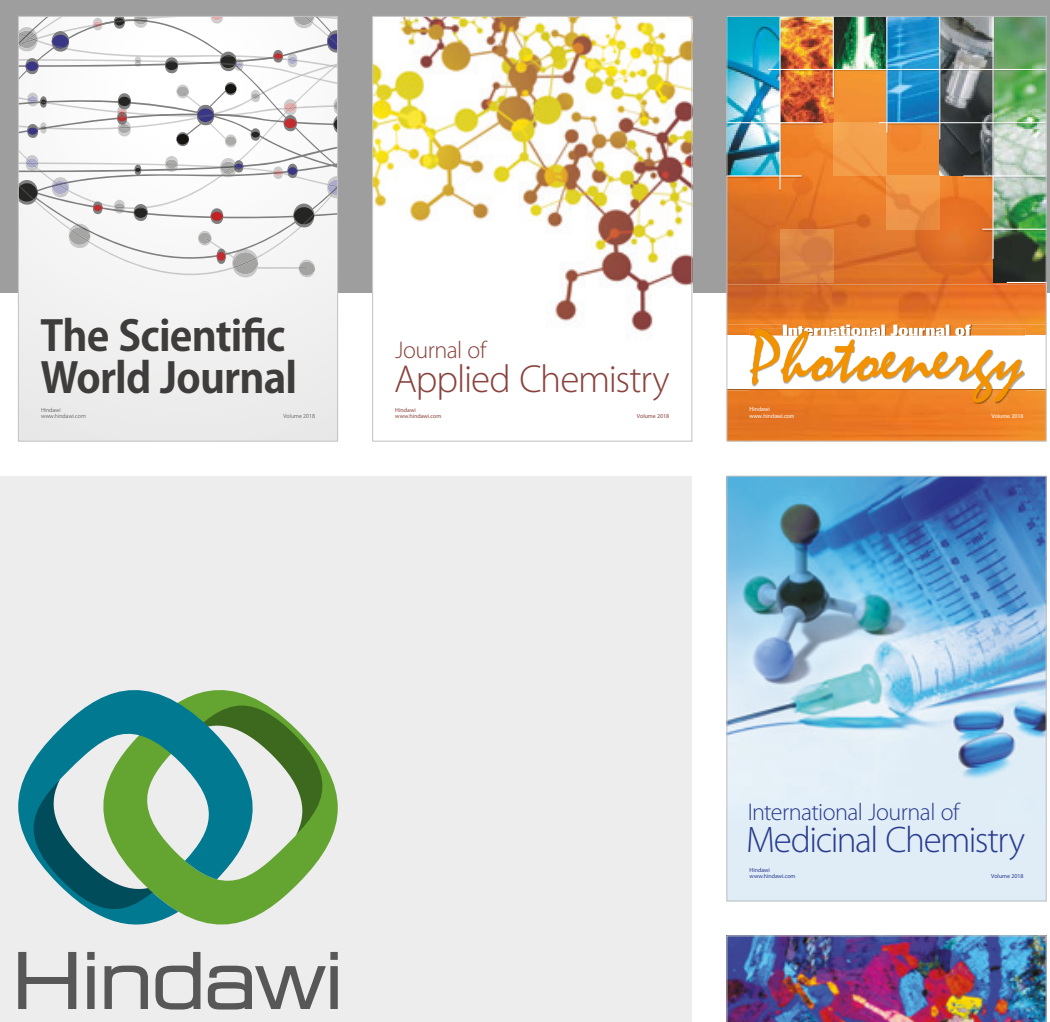

Submit your manuscripts at

www.hindawi.com
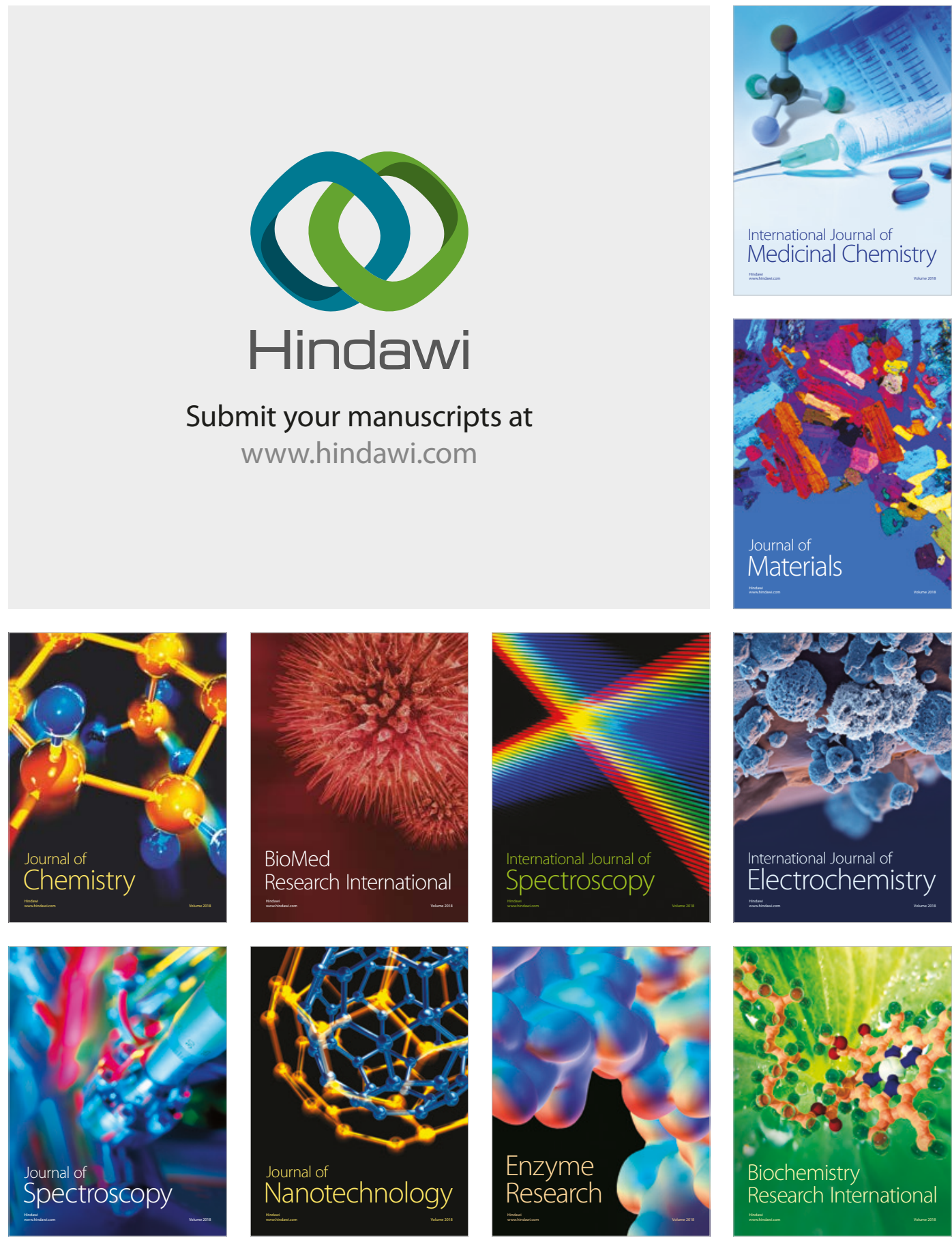
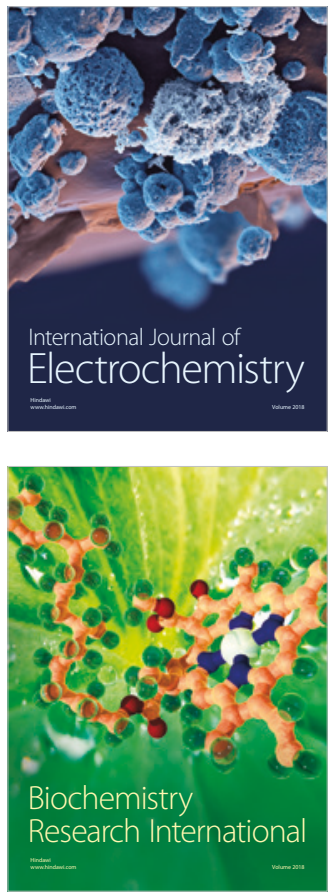